\title{
The Ontological Basis and Justification of Law
}

\author{
Michael M Uzomah \\ Philosophy Department, St. Albert Institute, \\ Fayit-Fadan, Kagoma, Via Kafanchan, Kaduna State. \\ Email: uzomahmikeabuchi@yahoo.com
}

(Received: May-2020; Reviewed: July-2020; Accepted: July-2020;

Avalaible Online: July-2020; Published: September-2020)

(7) (7) (5) This is an open access article distributed under the Creative Commons Attribution License
CC-BY-NC-4.0 (C2020 by author (https://creativecommons.org/licenses/by-nc/4.0/)

\begin{abstract}
This paper responds to the linchpin and central problem of jurisprudence in all its variants (legal schools) which is the task of establishing the meaning, nature and validity of law. The notion of validity and obligation is not only crucial to the concept of law, but also essentially inalienable. In the naturalist perception of law as well as in the positivist explication of law, the notion of validity is given fundamental attention. However, the point of disagreement or conflict, between legal naturalism and legal positivism (which are the two most outstanding and contending legal thoughts) revolves around the question: Where exactly does or from where does the law acquire its obligatory or binding or legal force? Differently put, in what does the validity of the law subsists? What invests a legal stamp or seal on a piece of legislation? Or what confers legality on legal norms that justifies and commands their obedience? While the naturalist appeal to some extra-legal, moral and metaphysical elements as the foundation of the binding force and validity of law (the oughts), the legal positivist took a formal and empirical approach to the explanation of the obligation and validity of law (law as it is, without recourse to metaphysical or moral oughts, is valid and commands unconditional obedience). Consequently, as an attempt towards establishing the ontological nature and justification of law, this paper defends the naturalist jurisprudence. The paper argues that to properly configure the true nature of positive laws otherwise called the jurisprudential laws in relation to law per se, the philosopher transcend the formalistic and materialistic study of law (empirical and descriptive) to the transcendental (prescriptive) examination of law not just in its ontological descriptive dimension, but most essentially in relation to its normative or prescriptive form. In lieu, the paper further argue that consequent upon the prescriptive nature of the law of nature, and the concomitant rational nature of man, positive laws cannot but inexorably be morally biased. The methods adopted by the research include the expository analytic and prescriptive methods.
\end{abstract}

Keywords: Morality; natural positive law; nature; obligation; ontology; order; validity. 


\section{INTRODUCTION}

In responds to the central problem of jurisprudence which is the task of establishing the meaning, nature and validity of law, this paper critically ruminates on the concept, meaning and nature of law, as a means of attempting a general conceptual and ontological configuration of law. The paper argues that to properly configure the true nature of positive laws otherwise called jurisprudential laws in relation to law per se, the philosopher transcends the formalistic and materialistic (empirical and descriptive) study of law to the transcendental (prescriptive) examination of law not just in its ontological descriptive dimension, but most essentially in relation to its normative or prescriptive form. The rational law of nature is the seal and imprimatur of derivative laws. In lieu, I further argue that consequent upon the prescriptive nature of the law of nature, and the concomitant rational nature of man, positive laws cannot but inexorably be morally biased. Because it is in the rational nature of man to discern what is morally permissible as far as law which is an ad hoc modality for social control and social intercourse is concern. Hence, in the making, interpretation and adjudication of law (litigation), man's moral idiosyncrasies must unavoidably come to bear (ie, law in every instance of its existence is subject to moral approbation and disapprobation). This of course is responsible for the controversial nature of law because of the element of relativism that is associated to the conceptualization of morality.

\section{WHAT IS LAW: COMPACT PHILOSOPHICAL QUESTION}

At the very commencement of this philosophical reflection and attempt towards a general conceptual and ontological configuration of law, it is germane to state ab initio that, the concept 'law' is notoriously a catchword in every human societies, organizations, associations and social arrangements; basically because it affects and influences man in every level of his experience, survival and flourishing in the society (Edor \& Odok 2017). Yet the question what is law is a trillion dollar and the grand of all jurisprudential questions. For other questions like, what is the origin of law? What are the fundamental validating elements of law? Etc., are subsumed in the mother of all jurisprudential question, what is law? The apparent question, what is law is one that is complex, ambiguous and perplexing owing to the fact that it entails the conceptualization and the unveiling of the ontological nature of law. The perplexity of this supposed simple question is comparable to the perplexity the philosopher Augustine of Hippo experienced with the concept of time. He once expressed this perplexity when he exclaimed, "I know what is time, but when you ask me to explain or define time, my knowledge of time eludes me". In other words, the perplexity associated to the concept of law, like that of time lies with its illusive nature. The illusive nature of law, responsible for the lack of a universally acceptable definition is expressed by Auden, a legal luminary when he was once confronted with the task of defining law, he gave the following tautological definition of law, "Law says the judge as he looks down his nose, speaking clearly and most severely. Law as I've told you before. Law is as you know he suppose. Law is but let me explain it once more, Law is the law" (Auden, 1984, p. 7). This tautological description of law implicitly and explicitly suggests that law is an a priori entity. Based on this token, it is plausible to assert that law can be rather described or configured than defined because law is law. In other words, it is safer to describe what law is than to define it.

The question of the definition of law has a long history in philosophical discourses and in fact, it remains a perennial question. "The question cannot be answered by simply describing some legal systems any more than the question "what is truth?" can be answered by simply talking about some truthful propositions (Omoregbe 1997, p. vi). According to Hart (cited in 
Omoregbe 1997, p. vi), "few questions concerning human society have been asked with such persistence, and answered by serious thinkers in many diverse, strange and even paradoxical ways as the question: What is law?". Hence, the concept of law is so simple, and yet has the same complexity with the concept of good which Moore declared as indefinable. This is because law in its ontological construct, is indivisible; if it is indivisible, it is indefinable and can only be described by means of exposing its fundamental characteristics.

The puzzle of the complexity of law is further heightened by the very fact that it could be perceived and explicated according to different perspectives, trends and interests. This has being a major obstacle to enunciating an exclusive definition of law (Uzomah 2015, p. 1). It is germane to assert that, apart from the fundamental fact that law by its nature is simple yet complex, one of the empirical facts that has continually militated against postulating a comprehensive definition of law that would be generally and universally accepted by scholars or thinkers of all disciplines and walks of life is that certain bias and prejudices that are factors associated to individual scholars' background inevitably influence their perception and interpretation or configuration of law. What I mean to say is that, individual legal theorists' reflections on law are infiltrated by psychological, religious, ethical and other value-laden extralegal factors and principles that constitute their background. This assumption is predicated on Bonsignore et al, (2007, p.1), who opined that:

Definitions of law are statements of believe akin to political philosophies, articles of faith in religion, or intuitions in science. The person who defines has a flash of genius, and the whole legal universe falls momentarily into place. Once a definition is reached, events are shaped to fit the definition, and what is at first only a psychic reality becomes a reality, "out there as well". It is this phenomenon that makes definitions so important and yet so dangerous; they provide concentrated explanations of the legal world but also foreclose possibilities that would disrupt the definition.

This implies that religious orientation, ideology, current, interest and other elements of a scholar's background necessarily interfere and colour his/her definition of the concept of law. This of course instigated Hans Kelson, the famous Pure Theory exponent to argue that the positive law has been saturated by extra-legal principles (psychological, metaphysical, moral, ethical, religious, etc. factors) that blur the true concept and conceptualization of law. He therefore, advocated that in order to fashion out a true and clear concept and conceptualization of law, all these extra-legal appendices must be extricated from the province of law.

Moreover, the puzzles inherent in the concept and nature of law have been outlined by Olajide (2017) in one of his Postgraduate Lectures, in 2013 precisely. According to him, any attempt towards the definition of law is confronted by the following clusters of questions, "What is law? Do we invent law? Or, is law nature itself? Does law ontologically coexist with nature? Is law out there imposing itself in our consciousness? Is law necessary or contingent? Is law and morality a unity? And as such enjoys an intrinsic, intimate and essential relationship, or is their union contingent? Olajide (2017) further argue that, to have a true grasp of what law consists of, one must seek to establish the sources to law. I said sources to law instead of sources of law for obvious reasons which shall be more explicit as this work progresses.

It is of paramount importance to emphasize that there is a fundamental difference between the phrase, "the sources of law", and "the sources to law". The basic difference lies with the fact that, while the former is a materialistic and empirical account of the origin of jurisprudential laws otherwise called derivative laws, the latter essentially points to the abode of generic law, which ought to be the basis of man-made laws. In other words, the latter is principally concerned with the paths that lead to law. Consequently, before attempting a definition of law, what follows is a concerted effort towards establishing the sources of law. In other words, our modus operandi is an a posterior approach, moving from what is known to the 
unknown, moving from the parlance of jurisprudential laws to the universe of generic law, otherwise known as law per se (law strictly so called), or the natural law.

\section{THE SOURCES OF LAW: (JURISPRUDENTIAL LAW)}

By the sources of law is implied the authority, institution or personality from which the jurisprudential laws of the state emerge. It refers to the corpus or legislative assembly from which legal rules that are accepted as binding on those who live under its jurisdiction within a sovereign state are issued, degreed, enacted and promulgated. Moreover, when we talk about the sources of law, we are primarily concerned about the formal and material sources, not of generic or law per se, but of municipal laws. When a legal positivist or a law student or a legal practitioner is asked to delineate the sources of law, he/she would almost intuitively and unconsciously respond that:

There are many factors of law that have contributed to the development of law. These factors are regarded as the sources of law. Legal customs, Divine right, Natural and legal rights, human rights, civil rights, and common law are often implied and unwritten sources of law that have been established over decades or centuries. Canon law and other forms of religious law form the basis for law derived from religious practices and doctrines or from sacred texts; this source of law is important where there is a state religion. Historical or judicial precedent and case law can modify or even create a source of law. The ultimate in written laws are the charter, the constitution, and the treaty, much of which form the foundation of modern legal systems. Legislation, rules, and regulations are often the source of laws which are codified and enforced by the legal system (en.wikipedia.org/wiki/sources_of_law).

In other words, according to a positivist account of law, there are basically two sources of law, former and material sources. According to Salmond, an English Jurist's classification, the sources of law include the following, formal sources and material sources.

\section{FORMAL SOURCES OF LAW}

By the former sources of law, the interest of the legal scholar is majorly on the sources of the validity of a legal rule or jurisprudential law. Questions pertaining to the former sources of law are principally concerned about the grand for the force and validity of a given legal system. In other words, it enquires about the pedigree and basis of the validity of a given piece of jurisprudential law. Hence, a scholar with a positivistic disposition considers only laws enacted by the State or Sovereign as components of this category. Moreover, for the positivist, it is the authority (legitimate) from which a piece of law issues that invests it with the character and substance of law (the law as 'it is' contain within itself the its validating element). Hence, when legal thinkers refer to former sources of positive law, their focal attention is on the basis of the coercive power and binding force of positive laws. It must not go without indicating that by former sources of law we imply the causal agent or efficient cause of law (the legitimate lawgiver). However, for the legal naturalist, establishing the former sources of positive laws, is not conclusive of the question of the validity of law, for this only accounts for law as 'it is', and not law as 'it ought to be'.

Unlike the former sources of law, questions pertaining to the material sources of law revolve around the material or matter from which a given piece of municipal law is derived. Here our concern is on the material cause of a given legal system. It refers to the material of law. Going by the material sources of law as categorized by J. O. Asein (2005), the following are the sources of jurisprudential laws: 
(a) The Constitution;

(b) Local Statutes;

(c) Case Law;

(d) English law, comprising pat of the Acts or Orders-in-Council applying directly to Nigeria, statutes of general application, the common law and doctrines of equity; and

(e) Customary law (2005, pp. 22-23.).

Material Sources of Law: However, a critical study of contemporary legal systems of nations reveals that there are three fundamental material sources of law, these include: Custom, Judicial precedent and Legislation. Moreover, in terms of comparative analysis, it is plausible to assert that most contemporary legal systems are based on legislations. According to Wale Olajide, in a recent postgraduate lecture (precisely, 2017) "Law by their nature are collective resolutions that grow out of specific debates and specific issues. Every law ought to grow out of debates based on issues". This description of the material origin of law refers to statutory laws. At the same time, it is equally true that sometimes customs play a significant role in the legal system of a country. In some of the legal systems, court decisions are binding as law. One of the schools of jurisprudence that construes case laws or statutes, or pronouncements of judges as law properly so is legal realism, a sub-school of legal positivism.

According to the realists laws made by judges are the real laws. They give less importance to the traditional rules and concepts as real sources of law. Realism is contrary to idealism; it is a combination of analytical positivism and sociological jurisprudence. Realists do not give much importance to laws enacted by legislative bodies and consider the judge-made laws as the actual law (Asein, 2005, pp. 97). Realists place great emphasis on the role of judges in the implementation, interpretation and development of law. Realists believe that the social, economic and psychological background of a judge plays an important part in his decisionmaking (Asein, 2005, pp. 97). Based on this token, they maintain that whatever law that proceed from the sovereign or legislative assemblies, strictly speaking are no laws, for them, laws, properly so-called is what the judge says the law is. The basic philosophy behind the realist underscoring of law is that, the judiciary has been saddled with the noble power or responsibility to interpret and adjudicate law. In pursuance, in the event of litigation or when the need arises to clarify misconceptions or ambiguities inherent in a given piece of jurisprudential law, it is the exclusive constitutional right of the court (customary, high, appeal or supreme courts) to define what the law is. And when this is being done, the lawgiver is never consulted to state what his intentions were at the moment of the enactment of the law in question. For instance, when the incumbent governor of Ekiti State, Ayodele Fayose was to contest for the 2015 Gubernatorial Election in Ekiti State, APC went to court to contest is legibility. APC as the complainant prayed the court to declare that since Fayose in his first term as governor was impeached and accused of mismanagement of public fund, by the letters of the law he is not legible for life to hold any public office again. However, after a brief period of litigation as stipulated by relevant extant electoral Acts, Fayose was absorb of any wrong doing. According to the trial judge, previously a legitimate court of competent jurisdiction has discharged and acquitted him. This judgment as given by this learned judge from the moment of its pronouncement became a law and a reference point for relevant cases in the future. Based on this historic example, the legal realists is right to have argued that it is the judge (pronouncements of court) that the authentic material source and arbiter of positive laws. This is because, after the judgment, the legislature cannot repeal or reject the pronouncements or verdicts of courts of law under the pretext that it wasn't what they legislated. The spoken words of judges in litigations and judicial enquiries are final and conclusive of law. Also, they are opened as authoritative reference points for future litigations. 
Even in the present dispensation, the National Dailies is replete with clashes between the National Assembly and the judiciary; every now and then, when the National Assembly either through its committee or the General House invites members of the Executive arm of government to appear before it based on their constitutional powers, the latter often runs to court to challenge their authority. And amazingly, the court often stalls or stops the National Assembly. The case of the IGP of Police and the Custom Boss is the latest in the series. What about the famous impeachment saga of Senator Melaye which the senate moved to prevent and of which Melaye prayed the court to stop, however, the court declared that the impeachment processes must continue in accordance with the law. These are only but few existential instances that validate the realists claim that the court or judges are the real and final material sources of law. Judge made laws are known in judicial precedence as case laws and they have the fullest force of law for courts of cognate jurisdictions, except a court of higher jurisdiction sets it aside.

Having ruminated on the former sources and material sources of positive laws, what follows is a critical expose of the ontological basis or fundamentals of positive laws. This is premised on the basic thesis that the former and material (empirical and descriptive) accounts of law are inconclusive of the question of the nature and validity of law. To attain a genuine conceptualization and ontological delineation of the nature of law, our analytic periscope is focused on navigating the parts that leads to the universe of the generic law or law per se or law of nature.

\section{THE IDEA OF LAW: THE PATHS THAT LEADS TO LAW (GENERIC LAW)}

The formalistic and materialistic approaches which together are categorized as the analytic or positivistic account presented above is inconclusive and incomplete as to provide the essentials that are inevitable for the definition of law. Law per se is profoundly fundamental and exclusive as to be restricted to its material and former perspectives. Hence, to give a genuine configuration of law, the scholar must go beyond the sources of law to the sources or paths to the abode of law in its generic or ontological status. As I have espoused elsewhere, "the positivists doctrine of law is formalistic and materialistic approaches to law which the philosopher must not be contented with. The philosopher takes the ground of all laws as his point of investigation. So, the veritable search for law transcends particular laws and legislators to the domain of law. The search for the ontology of law goes beyond law as "posited" to law as it "ought to be" (Uzomah, 2015, p. 3; Asuquo 2020; Mendie 2020). Against this backdrop reality, Olajide (cited in Uzomah, 2015, p. 3), postulates that, so:

When we are searching for the best means to bring peace and tranquility to man in his relationship with the transcendent we are searching for law. When we long for order and a harmonious social intercourse between individuals and individuals, and between individuals and the state, we are looking for law. When man seeks for modalities to harmonize his conduct to his immaterial essence, he travels on the path to law. When the legislators converge in their hallowed champers to debate on a particular bill in strict adherence to legal procedures, they are adventuring into the abode of law. These assumptions' according to Olajide, suggest that law is distinct from our affairs. Human experiences and contingencies necessitate the search for law. We become aware or conscious of law, we come to know about law, and that accounts for why when one discovers law, when one comes face to face to law, one necessarily respond to law by way of obedience because they copy from the nature of natural law which inexorably calls for an unconditional obedience.

On the formidable strength of Olajide's postulation above it is logically sound to adduce that, legislations (as well as other supposed material sources of law) are not sources of law, but source to law. In recognition of the metaphysical basis of law, one cannot but argue that "the 
question what is law cannot be answered from the empirical view point, but the answer must be sought from the metaphysical perspective becomes relevant (Kant, 1994, p. v). In other words, to postulate a good definition of law, the scholar must not be satisfied with knowledge furnished by the former and material interpretations of law, he must as a matter of compelling essence be acquitted with the ontological perceptive of law per se. This truism is aptly encapsulated by Obilade (cited in Uzomah, 2015 p. 3), who posited that "law is a complex phenomenon that any good definition of law must be complex, also shows that law encompasses both the empirical and supra-empirical spheres". Moreover, Ndubuisi, et al, (2007, p. 2), corroborated Obilade by asserting that "Law is a complex phenomenon because it is not easily discernible. This is true of all subjects that have intangible constituents in relation to the subject matter that deals with intangible constituents or values".

At this crucial point, the question we are to grapple with is, since by the basic thesis of this forgoing analysis, to arrive at a good configuration of law, the philosopher must not be satisfied with neither the former account of law nor the materialistic configuration of law; but focused on the metaphysical refection of law which basically is concerned with establishing the sources to law. The question is, what are the possible sources or path to the domain of generic law? How do we approach law in its generic and ontological status? A corollary to this question is, how does man came about the idea of law?

In what appears as a herculean attempt to establish the paths that lead to the universe of law, where the law of nature that stands as the validating ground and substance of jurisprudential laws reside, Burry Nicholas (cited in Uzomah, 2015 p. 4), suggested three ideas from which the concept and conceptualization of law were derived. The first idea of law is from the analogy between scientific laws and human law, the second is the idea from the notion of a higher law that brings an element of moral rectitude to those living under law, and the third, is the idea of law as the path on which community travels as an organic unit. These ideas, or if you, like ideals point to the domain of law qua law. It is in reflecting on these ideals that the lawgivers, whether as an assembly of persons or as a sovereign body journey towards the province of law. What follows is an elaboration of these ideas that constitute the paths or sources to law.

The first idea of law from analogy between human laws and scientific law could be construed to mean a scrupulous comparison between prescriptive laws and the descriptive laws inherent in the material universe. While the former is normative and formulated by man after the moral laws of nature, the latter is discovered by some privilege scientists (cited in Uzomah, 2015 p. 4). Plato, the man of unbridled idealism subscribed to the fact that law per se refers to the generic or descriptive law of nature. In Plato's dialogue Minos, Socrates gave only one definition of law: "The law, ho nomos, ... wishes bouletai, to be the discovery of what is, or "of being", tou ontos" (cited in Patrick Kernahan. 2004, 3.). So, in the Platonic sense, Law is the discovery and statement of what is, the things that are legitimately accepted. In Plato's understanding, what is the form of order, and this generic form of order (law) is eternal, indubitable and immutable. It is discovered not made, it unconditionally binds all created orders. No being in the material universe can break it without suffering a grave consequence. All the derivative laws of the Polis or Republic have their basis on this discovered pattern or seminal germ of order. An apt encapsulation of the ontological nature of law itself is as given by Olajide (cited in Uzomah, 2015, p. 3), thus:

There is law by itself, and law of itself. There is law generic that has a unique nature. Law is what it is. Law in its generic conceptualization is law qua law, or law as law. This law is not made but discovered, Once it is so discovered, it is for ever and ever... The singular nature of this generic law is eternal, uniformity and indivisibility. The nature of nature itself is the authoritative stamp of generic law. It is no subject to debate, review or modification or repeal. 
Descriptive laws of nature include the law of gravitational pull, laws of physics, and other natural laws that governs or determine the nature and essences of things. The descriptive law of nature limits all things, beings, existences and life forms to their natures and essences; for instance, the menstrual circle of women, reproduction and procreation (every animal give birth only to their kinds), the attraction of opposites, the magnetic force of love, the spinning of the planets around the sun, and a host of others. The hallmark of the descriptive law of nature as far as things and forces of nature are concerned is that it is the principle of order and harmony in the universe. The descriptive law of nature is said to be responsible for the relative harmony and equilibrium inherent in nature. Aquinas (1948) called this, the rational divine providence or governance of all in nature. Furthermore, Olajide postulated that, "And there is a derivative of law. Jurisprudence derives its nature from the generic law. Generic law is the substance that is shared by jurisprudential laws in all its forms".

However, this idea of law that juxtaposes the descriptive law of nature and the human law is lacking in principle. It failed to establish the real nature of the human law and from whence it emanates. This is because, the human law is not only descriptive, but it is more essentially, also prescriptive. This implies that, the generic law or law in its ontological status if it must be considered as the fountain head and final source of the human law, ought not to be only descriptive it must also be prescriptive in nature. It must be stated without equivocation that, the law of nature is one and indivisible simplicity, yet it has two dimensions. These two dimensions which is its descriptive and prescriptive nature imply one single indivisible absolute law. The law of nature otherwise referred to as the natural law has two dimensions-the descriptive dimension and the prescriptive or normative dimension. The descriptive dimension of the natural law points to the law of nature that regulates every created orders (human beings inclusive) otherwise construe as nature. This law is inexorable and no element, being or phenomenon in nature falls outside the grip of this law. The varieties of the descriptive law include, gravity, laws of physics, aero-dynamism, etc. According to the thinking of Aquinas (1948), the descriptive law of nature is called, eternal law because it rationally orders all in nature to eternity. This dimension of generic law is one that Olajide rightly argued that it is not susceptible to approbation or disapprobation (moral judgment).

However, it must be indicated that when legal naturalists (a position I am a strong exponent of) speak of the law of nature as the ideal foundation of positive laws, they invariably imply the prescriptive or normative dimension of the law of nature and not the descriptive that is not admissive of moral reckoning. Ideally, when the naturalists speak of the generic law being the foundation of positive laws, they presuppose the second dimension of the law of nature which essentially is normative. Whereas, the second dimension of the law of nature which is encapsulated in the second idea of law, refers to the natural law (moral laws of nature) in the understanding of legal naturalists. This perspective of the generic law or the law of nature in line with the basic thesis of legal naturalism applies principally and exclusively to man as a rational animal. The second idea of law concerns itself with the perception of a higher law believed to be divine; this law compels men to live just, honest and praiseworthy lives. This idea of law correlate with Aquinas' (1948) notion of the universal precepts of natural law, divinely ordained to make men good and avoid evil. Since the essence of jurisprudential law is to ensure order in the society of rational beings, for it to achieve this order, it must inhere the principle of order. And the perfectly suitable principle of order here referred to, are the rational moral laws of nature which align to the rational nature of man. My precise thesis here is, that which is rational must be properly ordered by rational principles that are archetypes of his constitution. Man by his rational constitution (and to some extent his transcendental positioning) is a beneficiary of law and reason. 
Relying on the principle of logical deduction, one can arguably assert that the second dimension of the law of nature, epitomized in the second idea of the source to law is enshrined in Emmanuel Kant's famous "universal moral law" which he holds to be categorically imperative upon all rational beings. This idea of a higher law induces men to live virtuously in conformity to the divine will of the originator of the perceived higher law. This idea connotes order and harmony between the human person and his divine essence. Equally, this idea of law established a link between the law of nature and the human law (Uzomah, 2015, p. 5). It emphasis the fact that municipal laws have no foundation outside the moral laws of nature. The rational moral laws of nature impact the nature and character of law to human positive laws. Of course, the existential or functional value of the rational (moral import) of law is to ensure that what is collective affirmed good according to the principle of sound reason and judgment be promulgated.

The third idea of law as the path, through which community travels, is essentially the core of idea of law. This is because law, be it of human invention or of divine origin, serves as a pathway through which a society or community heads towards their destination (Uzomah, 2015, p. 6). The human positive laws serve the function of rationally ordering all in the society towards a path of justice and human flourishing. In order words, rational rules are codified to guide and direct all coexisting within its jurisdiction.

Consequently, the second and the third idea of law represent the contextual and ontological meaning and sense of law of this term paper. These two ideas explicate on the ontological, functional and formal basis of the human law. Therefore, this term paper argues that as far as jurisprudential laws are concerned, tracing the ontological origin of law as law, one must pay deliberate and priority attention to the normative or prescriptive nature of the law of nature. This assumption is premised on the profound fact that the essential function and need for positive laws is to ensure order, harmony and peaceful coexistence of rational beings in the human society; to compel all in society to live in mutual respect of each other's rights and privileges; and, to ensure that one's civic duties and obligations to the state are conscientiously discharged. Moreover, to ensure that social compact between the state and its people is religiously respected. Also, laws of contract exist to ensure that those who enter into contract of any sort respect the terms of their contractual agreements, because is morally plausible to do that. Hence, the supreme good of every legal system ought to be to ensure that the good is done and promoted while evil is avoided and prohibited. This, of course, is the simplest definition of morality. Hence, if any legislation must serve its usefulness it must inhere these rational principles that constitute the teleology of rational beings. As I have argued elsewhere, the tenancy rate man pays as a rational moral agent and a social animal, is to be moral (to have a firm disposition to do good and avoid evil); and the law must continually either inspire or compel/coerce man to do so for him to achieve his sumuum bonuum.

It is instructive to observe that Plato did not only associated positive laws with the law of nature, he went ahead to establish that law is an expression of reason. According to Omoregbe (1997, p. 4), "He saw law as an expression of reason, and the ideal law as the law of Reason. For Plato, laws are necessary only when reason fails, for the law of reason is the ideal law. Plato is thus, the originator of the natural law tradition which identified the law of nature as a law of reason". Aristotle, the pupil of Plato defined law as an embodiment of reasons whether in individual or the community". By this configuration of law, it presupposes that for every piece of human legislation to acquire the character and nature of law it must be in tandem with the precepts of reason. By the very constitution of man, he is endowed with law (descriptive and prescriptive law) and reason. This assumption was made more significant by the notable Roman legal theorist, Cicero (cited in Olatunji, 1998:164), thus: 
For those creatures who have received the gift of reason from nature has also received right reason, and therefore they have also received the gift of law. Which is right reason applied to command and prohibition? And they have received law; they have also received justice.

For any piece of legislation to acquire the nomenclature 'law' it must be a precept of right reason applied to command and prohibitions. This implies that by the unconditional rational demand of the prescriptive law of nature, the human positive laws must promote the cause of justice. Promoting the cause of justice implies that it must be an embodiment of the common good of all living under its jurisdiction. The essence and goal of law must be the common good of peoples. The law must not be the reflection of the parochial interest or wish of a given individual(s), rather it embodies the generality of the aspirations, destiny and essence of the people. Common good is the fundamental value governing social life. Common good consists of three essential elements, namely: respect for persons, social wellbeing and development and peace. Therefore, the law is said to be good and just, when it promotes and guarantees these fundamental supreme goods of man. This, of course is the natural sense of justice deducible from the ontological moral nature of law per se (and this expresses the existential value of law).

Consequently, Ndubuisi et al (2007), admonished that, to arrive at a clearer vision of a genuine law, the philosopher of law is expected to provide us with lucid ontological explanation of the meaning of and purpose of law and bring into consciousness those extra-legal (metaphysical and moral) principles by which we can know whether a given law was fulfilling its purpose or not. Moreover, jurisprudence should always guide the legal order in making sure that law is not misconstrued. This is because according to him a wrong notion of law is bound to produce injustice and this will thereby defeat the right purpose for which law is made (Ndubuisi et al, 2007, p. 4). Little wonder then, Omoregbe (1997, p. 172), posited that "for the philosophical jurist, law is the expression of an idea. It is an expression of right and justice found rather than made by legislator or judge or text-writer". Law is the application of right reason for the rational ordering of social intercourse. It is ideally, a mimicking of the rational demands of man's rational nature for the right ordering of the society. Suffices it to assert that, the test of a genuine law is its reflection of the ontological moral nature of man. That is, its consistence with the principles of reason and justice, and its effectiveness in ensuring order in social intercourse.

In the final analysis therefore, a good account of the concept, nature and conceptualization of law, must go beyond law as it is (positive laws) to law as it ought to be (generic law, both in its descriptive and prescriptive ontological dimensions). Needless to state the implicit fact sufficiently evident in this foregoing analysis that, the generic law as it applies to all things in nature, beings, existences and elements pertains to the descriptive dimension of the law of nature. However, when humans are singled out from the universe of existences, beings and life forms, because of their unique endowment (rationality) the dimension of the generic law that is of utmost relevance is the prescriptive dimension of the law of nature. And it is this aspect of the law of nature that legal naturalists (of which I am an ardent defender) consider as the indubitable and incorrigible basis of positive laws. This perspective form of the law of nature demands equity, fairness, justice, rule of law and common good. Consequently, any piece of human legislation that goes contrary to the prescriptions of this law of nature is ipso facto null and void, therefore repugnant to good conscience. For, eo ipso no piece of human legislation has the power to confer legality or the force of law, except the law of nature which is the primordial or archetypal paradigm of law properly so-called. This of course justifies the basic thesis of this paper that it is in the nature of positive laws to be morally biased; because man by his ontological constitution is a rational moral agent and the supreme value of law in human society is to serve a moral good or purpose. This thesis is further given a 
firm footing by A. P. D. Entreves (cited in Omoregbe, 1997, p. 160), who aptly averred that, "the content of law is moral one because law is not only not only a measure of action, but a pronouncement on its values". Based on a sound deduction from Entrves' the moral nature of law, Omoregbe (Omoregbe, 1997, p. 160), argued that "another similarity law and morality have is that both are normative, prescriptive and imperative by nature since they are concerned with not with what "is", but with what "ought to be", not not with facts but with values". Having successfully described law from its ontological configuration, what follows is an attempt to define or conceptualize law from etymological perspectives.

\section{ON THE ETYMOLOGICAL MEANING OF THE CONCEPT OF LAW}

Etymologically, the concept "law" is derived from the Latin lex legis literarily, meaning "to bind". It is a rule and measure of conduct which is bidding on all under its jurisdiction. Lex expresses declared laws; it is essentially decrees from emperors. There is also another related concept, 'lus' which stands for customary law that is crystallized out of discussion (Dias, 1985, p. 47). Another Latin noun translated as law is Jus, jus is a law or right, the enforceable body of rules that govern any society. Jus, refers to one of the rules making up the body of Roman law, such as an Act of Parliament (Martin 2003, pp. 274-280). In the classical Roman legal system, there is yet another concept that was conceived as the spring-board of every human law - Jus Naturale. Jus Naturale was conceived by Roman legal theorists as, the fundamental element of all law. This Roman etymological configuration of law conforms with the second idea of the source to law which maintained the necessary causal and internal link between positive laws and the prescriptive law of nature.

From its Greek etymology, the concept law is derived from, nomos. Nomos means more than just a written, specific law in our sense; it means something like the principles and customs which guide the whole way of life of a community, including specific commands and prohibitions, of course, but also including accounts of the nature of things and justifications of the law itself (Kernahan p. 2004, p. 3). This implies that in the Greek worldview and cosmogony (as it is abundantly manifest in Greek philosophy), law as a measuring rod, as a rule and measure of human conduct that either induces actions or refrains actions, has its origin and justification in that which is the seminal principle or germ of law - the law of nature itself. Of course, needless to emphasize the obvious that, the whole idea of the prescriptive law, and perhaps, the descriptive law of nature being the ideal and the fundamental element of all law was initiated in Greek cosmology and philosophy. In other words, this is one of the outstanding eternal legacies of Greek philosophy to Western Philosophy and civilization.

For the Jews, the concept of law is derived from "Halakhah" its root meaning is "to walk' or 'to go. This concept literarily means the right path, the right course of action and the right way that leads to what is legitimately desirable. This essentially brings about the idea of law as the path that community travels. The Jews, believed (within Christian theology) to be the chosen people of Yahweh, strongly entertained this notion or view in their effort to realize God's plan on earth. Indeed for the Jews the Torah is the path to the divine, an indubitable way that guarantees peace and harmony in human community. Therefore, the Ten Commandments were given to Moses to order the life of the Israelites. The Torah acted as the fountainhead of all laws made by the Rabbi (Uzomah, 2018, p. 7). In this Jewish etymology, law is plausibly configured as the path that leads to human survival and flourishing. It is that which ensures that man is focused towards his teleology. The human positives laws are enacted as ad hoc modalities and pattern after the form of law to ensure man remains true to his essence of living in the society; also, to keep man align or inclined to his moral essence. This is why law is inevitable in the human society because it is of the essence of man. It is of the essence of man in 
twofold: temporal and divine. Hence, "the proper effect of law is to lead its subjects to their proper virtue . . . to make those to whom it is given good." The only "true ground" of the lawmaker is the intention to secure "the common good regulated according to divine justice," and thus it follows that "the effect of the law is to make people good" (Aquinas cited in Stumpf. and Fieser J. 2008, pp.179-180).

\section{TOWARDS A FUNCTIONAL CONCEPTUALIZATION OF LAW}

From the above attempt towards delineating a general conception of law from the sources of the idea of law and from the etymological meaning of the concept of law, it could be observed that law is a whole complex concept, yet it is ubiquitous. Although it has varied meanings and connotations, it is basically a rule and measures of both human conduct and of societal life. It serves as a guiding principle to peoples and institutions in all walks of life. Law has been instrumental to the economic, academic, social and religious spheres (Edor \& Ayuk 2020), as it regulates human experience in all levels of life in the society. It instills discipline and forestalls irresponsibility among peoples. It is conventionally conceived to be one of the formidable forces that had united nations all over the globe, and also responsible for the relative harmony in the universe (Aquinas cited in Stumpf and Fieser J. 2008, pp.179-180). Law in practice appears to be a form of inconveniences, especially to the wicked or the mischievous, because it compels or coerces people to do what ordinarily they would have not loved doing. This is why the great scholastic mind, Aquinas (1948) averred that law is made so that for fear thereof wickedness may be deterred and innocence safeguarded. This implies that for rebels and deviants, the law is a great incontinence, but for the innocent- those who abide by their innate sense of law, those who in their conduct and behaviour abide by natural sense of justice, the human law doesn't exists, if it exists at all it is a safeguard and an arbiter of tranquility.

Another relevant conception of law deducible from the above is that law is a cultural concept which is to serve a value (Kurt 1950, p. 73). This idea views law as a cultural element, and an element that gives people living under it a moral rectitude. It stipulates code of standards, and forms the yardstick and parameter by which the values of a people are articulated. This sense of law reflects the sociological concept of law. Sociology of law attempts to answer theoretical and practical questions about the growth of legal institutions and the place of law in society. According to Davis (1965, p. 301), for sociologists, "Law is part of the larger system of pressures towards conformity and attempts to prevent deviation from social norms that are termed "social control". Basically, from the sociological point of view, law functionally conceived is a mechanism for social control, cohesion and to ensure harmonious socialization. As an ad hoc modality for social control, law is fashioned to guide against malfeasance or sleaze in the society.

It is pertinent to observe that albeit, beside positive laws, there are other systems of social control within a given state or society, however, law is not just like other modalities of state control owing to its unique nature. This statement of facts finds its justification in Plerre Bourdieu (1987, p. 808), who asserted that “...Neither is the law just a reflection of these other modalities of state control. On the contrary, the law has its own complex, specific, and often antagonistic relation to the exercise of such power. Law as we have seen thus far is complex, yet it speaks to specific situations because the language of the law is precise and in most cases unambiguous. Law could be understood as being antagonistic, perhaps because it is always stated in the negative. In most instances the law offers prohibitions and sanctions to be meted out on those who contradict what the law proscribes or outlaws.

Moreover, one of the unique character or nature of law that places it at the pride of place it occupies over and above other modalities of social control is the fact that, the law is only the 
institution of the state that itself instituted the state and all other institutions of the state. Every state and their institutions and structures are creations of the law; and they are accordingly regulated according to the dictates of the law. Therefore, the law is a formidable instrument for social structuring, because being the vital force of the society, the survival and flourishing of all in the society and the society itself depends on the law. This is why am an ardent defender of the view that law is of the essence of man and society; because the survival of humans and societies is impossible without law.

Law has a very irresistible and indomitable social linguistic power. Through this linguistic power, it confers, commands and prohibits. It confers power and rights and denies the same. The linguistic power of the law is authoritative and unequivocal. This implies that with words, law gets things done. Bourdieu devotes particular attention to this special linguistic and social power of the law "to do things with words." Essential to that capacity, to the law's reproduction and continuation, to its legitimation in the eyes of those under its jurisdiction is what Bourdieu terms the law's "power of form." This power inheres in the law's constitutive tendency to formalize and to codify everything which enters its field of vision (Bourdieu, 1987, p. 808). Based on this token, one can plausibly argue that the texts of the law are thus quintessentially texts which produce their own effects. And the ideal effects of an authentic legal system is to ensure common good, justice, equity, fairness, and most essentially to ensure that the collective moral sensibilities of all is preserved and protected.

The fact that the law is different from other modalities for social control cannot be over emphasized. According to Radcle Brown (1959, pp. 206-208), law differs from many other social controls in being external, formal, and negative. Social controls are both internal and external. Observance of the law by most members of a society may be largely a matter of controls internalized in the course of socialization. However, no social control system depends entirely on internal controls. There are always imperfect or incomplete internalizations, and external controls are invoked both directly and indirectly. Law is a formalized imperative that must refrain people from acting and compels certain agencies that enforce its pronouncements. One other characteristic of law is that its enforcement is predicated primarily upon the external application of sanctions. Some norms are informally understood customs carrying customary, informal, or diffuse sanctions (Akers 1965, pp. 302). Others are formal, explicitly stated, and often written; they carry regular, organized, and specifically applied sanctions. Legal norms and sanctions are of the latter, formal type (Brown, pp. 206-208). Specific legal norms address specific issues and realities or social needs of man and society. This is to say, there is no general law for everything, rather, there are specific laws for specific issues or social realities; and the push to obey law does not just result from internal impulse, by influenced by external agencies as stipulated by law.

Lastly, in the sense that legal sanctions include punishment for depict rather than reward for right behavior, they are negative (Edor 2016). In law no provision is made to reward the obedient; there is only negative reaction to lawbreakers (Brown, pp. 206-208). Law is in the habit of stipulating punitive measures the state is to pronounce and enforce in the event of the transgression of any section(s) or subsections of the law. In this sense, jurisprudential laws by nature could be seen as negatively inconveniencing. According to W. Olajide (2017, no. p), "Laws by nature are both positive and negative. The positivity of the law is revealed in its insistence on unconditional obedience. Its negativity is in what will happen in case of noncompliance, disobedience and denial". This is why the legal positivist John Austin gives premium to the coercive imperative of the law, or the fear of evil consequences of the law as the seal of validity and the vital force of law.

As it were, law has been present in all known human society, whether primitive or civilized; man has always being governed by a body of rules which its members consider as the 
standard of conduct. This of course informed the Latin legal maxim, 'ubi societas, ubi jus', which implies, where there is society, there is law. The difficulty of studying law crossculturally has been precisely this lack of clarity about the class of behavior or the part of the whole meant by the term "law" (Akers, 1965, p. 301). With greater clarity about the class of phenomena to be considered under law, important theoretical questions can be asked. For instance, we may hypothesize that law becomes more important as a social control as technological development increases, but only if we know what is meant by law. If the definition includes all sanctioning and enforcing devices, the statement is doubtful and too diffuse to test readily. On the other hand, if the definition includes only the kind of legal machinery found in advanced societies, the hypothesis is a tautology (Akers, 1965, p. 301).

To resolve the above contention, Obilade wisely noted that it is only when those rules presupposes the idea of obligation that they become law, when they merely represent the notion of good and bad behavior, they are rules of morality. Law then consists of rules that are binding on its subjects, for the immediate aim of the right ordering of human affairs. J. H. Driberry (cited in Akers, 1965, p. 302), suggests that, ". . law comprises all those rules of conduct which regulate the behavior of individuals and communities". The basic difference between legal rules and moral rules is that legal rules are enforceable. This implies that when legal rules are bridge, it attracts legitimate sanction in the form of punishment or other remedies as stipulated by the same law. Moral rules only acquire the form or force of law when they have been included into the legal system through the formal procedures of enactment (Edor 2016). So, it is the duty of the law to recognize a popular objective positive morality by enacting them into law.

To further delineate the striking difference between moral rules and legal rules, Hoebel's postulations becomes very apt. Hoebel identifies privileged force, official authority, and regularity as the common elements that constitute the sine qua non of law. These common elements epitomize "the legitimate use of physical coercion by a socially authorized agent". The force may be actual or implied but must be for legitimate cause. Physical coercion otherwise is feud, vendetta, abuse, gangsterism, or something else-not law. Hoebel's emphasis on force resembles Weber's "coercive apparatus" in readiness for norm enforcement (cited in Akers, 1965 , p. 303). In other words, wherever a piece of legislation is found, for it to be construed as a component of a legal system (from the formal and material perspective), privileged force, official authority, and regularity must be its fundamental elements. Furthermore, Hoebel noted that, the coercion need not be applied, but the probability of its application must be recognized (in other words, coercion is only to be applied as a final resort). It is germane to add that law enforcement agencies be cautious in the application of force, less they become brutal, and just a step away from 'jungle justice.

\section{THE NOTION OF OBLIGATION AND SCHOOLS OF JURISPRUDENCE}

That philosophers, Jurists and legal scholars have not arrived at a unanimous definition of law is a phenomenal fact. One of the central problems militating against the definition of law subsists in the unresolved issues pertaining to the basis of the binding force or obligation to obey law. The notion of binding or obligation is essential to the proper conception of law. The unresolved issue remains: where does a law derive its binding force or imperative? At what point can a law be said to be binding or not? In jurisprudential studies, the issue of the basis of legal obligation is known as the 'is-ought' dichotomy or palaver. This dichotomy entails the polemics surrounding law 'as it is' and law 'as it ought to be'. The concerted or painstaking attempts of scholars of all ages and orientations to sufficiently account for the foundation of legal obligation have given rise to the definition of law from philosophical, theological, historical, social and realistic perspectives and interests. It is because of these different 
approaches that different concepts of law and consequently various schools of law have emerged. Jurists hold different perceptions and understanding of what constitutes the law and legal systems. In other words, an attempt to solve this puzzle has led to the parallel between the naturalist and the positivist bi-polarization. I mean, this has given rise to the disparaging positions of the naturalist and the positivist. While the positivists see law as 'it is' as sufficient and conclusive of the question of obedience and obligation to law; the naturalist look beyond law as 'it is' to some extra legal principles (law as 'it ought to be') as the foundation of legal obligation and obedience. Consequently, the polemics or altercation surrounding the basis for legal obligation has polarized legal theorists and thinkers into different jurisprudential schools of thoughts.

In his book, The Science of Law, Karl Gareis (cited in Akers, 1965, p. 303), distinguished between three schools of jurisprudence, namely, philosophical, historical jurisprudence, and analytic jurisprudence. What Karl Gareis described here as philosophical jurisprudence is represented by the natural law school. His other two schools namely, historical jurisprudence and analytical jurisprudence can be conveniently classified together under the term "the science of law". Thus, there are basically two schools of jurisprudence, the philosophical school and the scientific school (all other classification of jurisprudence are sub- schools of legal positivism because in one way of the other they are reacting to the basic thesis of legal naturalism). What the latter does is the science of law. That is, an a posteriori, empirical study of law. What the former does is the philosophy of law, an a priori, metaphysical approach to the study of law.

In this light, it can be seen that legal positivism is not a philosophy of law but science of law. The philosophy of law is not the study of particular sets of laws of a given society or a given epoch, nor is it the study of legal systems, but rather the study of the universal and permanent features of law. The philosophy of law cannot be reduced to the study of facts as they, but rather the study of the universal criterion for judging facts. In other words, philosophy of law is not fact oriented, but value oriented. ${ }^{49}$ In a concise manner, the legal scholar, R. M. Pizzorni (cited in Omoregbe, 1997, p. 173), classified into three, the main objects of the philosophy of law: i. The universal concept of law, that is, its essential features which must be present in every judicial system; ii. The foundation of law from which every legal system derives its origin and value; iii. The standard or criterion with which all existing laws are guided and evaluated. For the problem of the evaluation of law is the problem of philosophical jurisprudence.

The analytic jurisprudence is championed by Legal Positivism, which holds that law properly so-called is law as 'it is in the legal system or if you like in law books. Some notable defenders of legal positivism include; Jeremy Bentham, John Austin, Hans Kelson and H. L.A Hart. The basic thesis of the Natural law school that holds the precepts of the natural law as the inexorable basis of legal obligation was rejected by Bentham and Austin in the nineteenth century on the pretext that the natural law doctrine is vague and ambiguous in nature. However, undue emphasis on positivism and rejection of morality as an element of law reduced the law into a command of a gunman and therefore, failed to satisfy the aspirations of the people. It was realised that over-emphasis on the historical approaches to law had led to the rise of fascism in Italy and Nazism in Germany (http://www.hcmadras.tn.nic.in/jacedemiy/ar ticle/law20of\%20pre\%20by\%20MSK\%20Adv.pdf). Even in our contemporary day, undue stress on positivism at the grave expense of naturalism has given rise to the insurgency of homosexuality, clamour for the legitimization of right to suicide, euthanasia, abortion, and other acts and attitudes considered as unnatural to man and contrary to the ontological moral worth of man. Consequently:

The change in socio-political conditions of the world, like the rise of materialism after the First World War, shook the conscience of the western society. It compelled the twentieth 
century western legal thinkers to ponder over the existing legal regimes, so as to provide some alternatives based on value-oriented ideology and to check moral degradation of the society. These factors led to the revival of natural law theory in its modified form, which is different from its traditional form (Ibid).

This gave rise to the resurrection or resuscitation of the doctrine of natural law. Natural law in its new form is value-oriented and value-conscious. It is neither permanent nor everlasting in character and it is relative, not absolute in nature. For instance, in modern times procedural as well as substantive laws have to be just, fair and reasonable. Generally, the 'rule of law' and 'due process of law' are considered as new incarnations of natural justice in the twentieth century (Ibid). Rudolf Stammler, a German jurist, John Rawls, an American philosopher Kohler, a German Jurist, and others, contributed to the revival of natural law in the twentieth century. The principles of natural law have also been inspired by the emergence of the modern philosophy of human rights (Ibid).

It is informative to observe that part from this broad categorization of jurisprudence into philosophical jurisprudence and the science of law (scientific jurisprudence); jurisprudence could also be classified as follows: Legal Naturalism, Legal Positivism, Legal Realism, Historical and Anthropological Jurisprudence, Sociological Jurisprudence, Marxist Jurisprudence and, most recently, Feminist Jurisprudence. It suffices state that apart from Feminist Jurisprudence, and perhaps Marxist Jurisprudence, all other forms of jurisprudence either directly or indirectly are significant and positive objections to the natural law school, otherwise known as philosophical jurisprudence. Notwithstanding the deferring positions of the different schools of jurisprudence, they are united in the profound belief that law is essential for social control and for the rational ordering of all in the society.

\section{CONCLUSION}

In an attempt to provide a general conceptualization and ontological configuration of law, this paper critically reflected on the concept, meaning and nature of law. It has been crystalline that law is a simple concept yet has the same complexity and illusive nature with the concept of good and time which appear indefinable. It has also been crystalline that the complexity of law hinges on the fact that it consists of both empirical (former and material elements) and metaphysical (extra-legal principles) dimensions. Therefore, I argued that to properly configure the true nature of positive laws otherwise called the jurisprudential laws in relation to law per se, the philosopher transcend the formalistic and materialistic study of law (empirical and descriptive) to the transcendental (prescriptive) examination of law not just in its ontological descriptive dimension, but most essentially in relation to its normative or prescriptive form. In lieu, I further argue that consequent upon the prescriptive nature of the law of nature, and the concomitant rational nature of man, positive laws cannot but inexorably be morally biased. Because it is in the rational nature of man to discern what is morally permissible as far as law which is a modality of social control and social intercourse is concern. Hence, in the making, interpretation and adjudication of law (litigation), man's moral idiosyncrasies must unavoidably come to bear. This of course is responsible for the controversial nature of law because of the element of relativism that is associated to the conceptualization of morality. Nevertheless, the internal relations between law and morals is so profoundly intertwined to point that despite the concerted efforts of positivists to extricate both, morality has not been successfully sequestered from law. Hence, a genuine law, properly so-called must have the imprimatur of natural law for its authentication and validation. In conclusion, the ultimate aim of law is to ensure justice for the peaceful co-existence of all. However, law in its concrete 
application has been seen to fall short of this mark owing to its inability to ensure perfect justice.

\section{REFERENCES}

Akers, R. L. (1965). "Toward a Comparative Definition of Law", Journal of Criminal Law and Criminology. Volume 56, Issue 3 September Article 5, Fall.

Aquinas, T. (1948). Summa Theologia, Trans. By Frs. English Dominican, New York: Benziger Brothers Inc. Vol. 2.

Asein, J. O. (2005). Introduction to Nigerian Legal System, $2^{\text {nd }}$ ed., Lagos: Ababa Press Ltd., 2005.

Asuquo, G. (2019). Liberalism and Its Implication for African Thought in the 21st Century: A Critical Analysis. GNOSI: An Interdisciplinary Journal of Human Theory and Praxis, 2(2), 31-39.

Bonsignore, John et al, (2007). Before the Law: An Introduction to Legal Process, Boston: Houghton Mafflin Company.

Bourdieu, P. (1987). "The Force of Law: Toward a Sociology of the Juridical Field", The

Hastings Law Journal. Vol. 38, July.

Dias, R. D. M. (1985). Jurisprudence, London: Buther Worths.

Edor, J. E. (2016). Capital punishment: focus on the sanctity of human life in (Boki). Sapientia: Journal of Philosophy 6 (April), 86-102

Edor, J. E. (2016). Wither the "Evil" of Capital Punishment: Focus on the Sixth Commandment of the Decalogue. The Oracle: International Journal of Culture, Religion and Society 3(4), 102-120.

Edor, J. E., \& Ayuk, T. O. (2020). Religious Extremism: A threat to Nigerian Corporate Existence. Journal of the Social Sciences. 48(2).

Edor, J. E., \& Odok, J. A. (2010). The Marxian School of Law and the Nigerian Legal System. The International Researcher, 1(4).

en.wikipedia.org/wiki/sources_of_law

Kant, E. (1994). Ground Work on Metaphysics of Morals, trans, London: Hutchin University Library.

Kernahan, P. (2004). "The Meaning of Law: Plato's Minos. In On Religion and Politics”, ed. C. Lovett and P. Kernahan, Vienna: IWM Junior Visiting Fellows' Conferences, Vol. 13.

Kurt, W. (1950). The Legal Philosophies of LaskRadbruch and Dabin, London: Oxford University Press.

Martin, E. A. (ed), (2003). A Dictionary of Law, Fifth Edition, Oxford: University Press.

Mendie, J. G. (2020). Metaphysics and the Method of Ibuanyidanda. GNOSI: An Interdisciplinary Journal of Human Theory and Praxis, 3(1), 32-39.

Ndubuisi, F. N. et al. (2007). Issues in Jurisprudence and Principles of Human Rights, Lagos: Foresight Press Ltd.

Olajide, W. (2017). Lectures on Philosophy of Law, "Postgraduate Course Work", Ekiti State University, Ado-Ekiti, Unpublished.

Omoregbe, J. (1997). An Introduction to Philosophical Jurisprudence, Lagos: Joja Educational Research and Publication Limited.

Stumpf, S. E. and Fieser, J. (2008). .Philosophy: A Historical Survey with Essential Readings, Ninth Edition, New York: McGraw-Hill Education.

Uzomah, M. M. (2015). The Natural Law as the Basis of the Human Law: A Philosophical Appraisal, An MA Thesis Submitted to the Department of Philosophy, Ekiti State University, Ado-Ekiti. 
168

Pinisi Discretion Review

Volume 4, Issue 1, September, 2020 Page. 151- 170

Uzomah, M. M. (2018). The Concept of Law: An Ontological Conceptualization of the Basis of Law. Kafanchan: De-young Printing Press. 
Michael M Uzomah; The Ontological Basis and Justification of Law|169 